\title{
Barack Овama's Address to the 2004 Democratic national Convention: Trauma, Compromise, Consilience, AND tHe (IM)POSSIBILITY OF RACIAL RECONCILIATION
}

\author{
David A. Frank and Mark Lawrence McPhail
}

The two authors of this article offer alternative readings of Barack Obama's July 27, 2004, address to the 2004 Democratic National Convention (DNC) as an experiment in interracial collaborative rhetorical criticism, one in which they "write together separately." David A. Frank judges Obama's speech a prophetic effort advancing the cause of racial healing. Mark Lawrence McPhail finds Obama's speech, particularly when it is compared to Reverend Al Sharpton's DNC speech of July 28, 2004, an old vision of racelessness. Despite their different readings of Obama's address, both authors conclude that rhetorical scholars have an important role to play in cultivating a climate of racial reconciliation.

$\mathbf{I}_{\mathrm{D}}^{\mathrm{II}}$ llinois state senator Barack Obama's keynote address to the 2004 Democratic National Convention marked an important moment in the trajectory of African American rhetoric. His speech earned two reasonable responses, one upward-inflected and the other downward-inflected. ${ }^{1}$ For one of the authors of this essay, David A. Frank, Obama articulates a post-civil rights rhetoric intended to bring the various components of his composite audience (an audience "embracing people differing in character, loyalties, and functions") into rapprochement. ${ }^{2}$ The core value at the center of Obama's speech is the essential equality of created individuals, and the mood he sought to cultivate is one of "audacious hope." Working from these foundations, Obama nests the traumas of slavery and racism with those suffered by American workers lacking a living wage and affordable health care, the bigotry

David A. Frank is Professor of Rhetoric in the Robert D. Clark Honors College at the University of Oregon, Eugene. Mark Lawrence McPhail is Professor of Interdisciplinary Studies in the Western College Program at Miami University in Oxford, Ohio.

(C) Rhetoric \& Public Affairs

Vol. 8, No. 4, 2005, pp. 571-594

ISSN 1094-8392 
faced by gays and Arab Americans, and an America in the wake of 9/11. Commencing from these disparate traumas, Obama encourages his composite audience to walk the path of commonality, and in the process, offers a rhetoric of consilience, an approach in which disparate members of a composite audience are invited to "jump together" out of their separate experiences in favor of a common set of values or aspirations. ${ }^{3}$

Obama's rhetoric of consilience can foster reconciliation. It also is the symbolic strategy of what Mark Lawrence McPhail terms "coherence" (a conscious understanding and integration of difference in order to transform division) because it acknowledges that many members of his composite audience have and are suffering from shared and unique traumas that can be worked through with multiracial and class coalitions appealing to the ideal of justice. In contrast to Reverend Al Sharpton's speech, which emphasized the African American trauma, Obama's rhetoric of consilience offers an effective discursive strategy for working through the trauma of slavery and segregation, emphasizing the essential nature of human equality and the need for multiple agencies of responsibility and action. ${ }^{4}$ It thus has the potential of moving Americans beyond the complicity of racial division and toward coherent reconciliation. ${ }^{5}$

For author Mark Lawrence McPhail, Obama's speech offers little hope for reconciling an America divided by racial difference and indifference. Compared to Reverend Sharpton's speech, Obama's message ignored and obscured America's racial realities, and even though both men expressed faith in an idealized America, just the mention of racial issues earned Sharpton the dubious (dis)honor of "having hijacked the convention."6 Both speeches reflect, albeit differently, what W. E. B. Du Bois described as the twoness of black discourse and identity: the double-consciousness of being both African and American, ${ }^{7}$ and each reveals the tension between believing in the "promise" of American ideals and the knowledge of the broken promises of America's racial realities. Obama's "post-racial" rhetoric was celebrated and embraced as a "transcendence of the very concerns that minority politicians have championed in the Party for decades." ${ }^{8}$ Juxtaposed against Sharpton's address, Barack Obama's rhetoric reveals "a troubling public expectation ... that yearns for a denial of America's racial history as well as its contemporary consequences." Indeed, the response to Sharpton's address suggests that even the indirect referencing of racism continues to traumatize many white Americans, and it is their trauma that must be addressed if we are to consider seriously the possibility of coherent racial reconciliation.

For McPhail, the positive response to Obama's address should then be read not as a new vision of race, but as an old vision of racelessness that warrants a critical response comparable to that offered by Socrates in the dialogue 
Menexenus: "there is no difficulty in a man's winning applause when he is contending for fame among the persons whom he is praising." ${ }^{0}$ Obama's speech appeals to those ideological impulses at work in the rhetoric of white racial recovery, ${ }^{11}$ and the conception of equality he embraces reifies the ideologies of innocence and positive self-presentation that characterize contemporary rhetorics of whiteness and modern racism. ${ }^{12}$ Obama appeals to the abstractions and ideals of a transcendent social contract while obscuring or ignoring altogether the traumatic causes and consequences of America's racial past: what Charles W. Mills calls the "Racial Contract." ${ }^{13}$ In contrast to the rhetorical strategy of re-signing the racial contract, Obama resigns race for his audience, and eliminates any need for Americans to address the symbolic and social pathologies of white privilege and power.

We approach these two reasonable responses to Obama's speech as an experiment in rhetorical criticism, David A. Frank as a white American of Jewish and Quaker heritage, and Mark Lawrence McPhail as an African American influenced by Eastern spiritual philosophies. As rhetorical scholars we share both an interest in collaboration and a willingness to weave together voices that have different interpretations of Obama's address into a narrative that results in what Chaïm Perelman and Lucie Olbrechts-Tyteca call a "contact of minds." 14 We acknowledge that our judgments of the Obama address are influenced by our ethnic and cultural backgrounds, and accordingly we "write together separately." 15 Ultimately, we see our effort as both a problematic and a potentially fruitful endeavor to address rhetorical theory and public discourse as they deal with issues of race. While we disagree on many points about Obama's speech, we nonetheless agree on the importance of, and need for, racial reconciliation.

Toward this end, we have divided the paper into three sections. In the first section, David Frank offers an upward-inflected assessment of Obama's speech as an act of "working through" trauma with a rhetoric of consilience. Mark McPhail responds by countering that the Obama speech compromises its rhetorical coherence by maximizing the abstract ideals of the social contract while minimizing the concrete realities of the racial contract. Obama's address does indeed signal a "post-racial" rhetorical shift toward coherence, yet the degree to which this shift can move African and European Americans beyond the divisions of historic and contemporary racial traumas constitutes the stasis of our debate. In order to move beyond debate and toward dialogue, we conclude by considering the possibilities that our alternative readings of Obama's address might offer for enriching rhetorical studies of racial reconciliation, and the challenges and opportunities that our collaboration presents for studying the rhetoric of racism. 


\section{David A. Frank: In Celebration of Obama's Rhetoric OF CONSILIENCE}

The speeches Obama and Sharpton delivered to the convention represent two narrative responses to the traumas suffered by African Americans. These speeches, I believe, illustrate the intertwining of psychology and rhetoric; the continuing legacy of rhetoric, particularly when cast to persuade the composite audience, in affecting material, legal, and cultural change for African Americans; and the power of Obama's speech as a prophetic multiracial narrative. Rhetoric, and in particular, narratives, are critically important in managing trauma. Jerome D. Frank and Julia B. Frank observe in their definitive Persuasion and Healing: "rhetoric and a related discipline, hermeneutics, may prove to have more in common with psychotherapy than either religion or empiricism." 16 Dominick LaCapra, in a series of books, explains how narratives can "act out" and "work through" the consequences of trauma. ${ }^{17}$ The perceived absence of metaphysical foundations for justice and value choice and such historical losses as slavery, the Holocaust, and other traumas can provoke "acting out" (the repetitive rehearsal of a past trauma) and invite "working through" (an act of analysis producing interpretations allowing for responsible control of trauma) through symbolic and nonsymbolic action. Reading African American discourse through the prism of trauma studies weds psychology and rhetoric. This reading begins with the pathologies left in the wake of slavery and segregation, the primary exigence inviting the discursive responses of African Americans, and, I believe, the key roles played by social movement rhetoric, oratory, and argument in the dismantlement of slavery and legal segregation, striking achievements that must be yoked to the traumatic aftershocks that these two institutions created.

These aftershocks, and continuing de facto racism, help to explain the plight faced by African Americans in this century. ${ }^{18}$ With the fall of institutionalized slavery in the nineteenth century and legal segregation in the twentieth century, blacks made significant progress. I acknowledge that this progress should be read contrapuntally with trends of resegregation and the continuing disparities between whites and African Americans. While pointing to the significant progress that African Americans have made since the civil rights era in income, ownership of homes, voting, and education, Lee A. Daniels and Rose Jefferson-Frazier in their National Urban League report nonetheless observe that "there are still notable gaps between African Americans and whites, especially in the area of economics that reveal major challenges in the pursuit of equality and opportunity."19 Their report documents evidence of progress and regress, a warrant for both optimism and skepticism. The progress that has been made is due, in part, 
to the construction and reconstruction of narratives and an adroit use of the symbol, a legacy justifying some hope for the present and future.

The institution of slavery, which endured for over 244 years, eventually yielded to the Quaker-inspired abolition movement, reflecting the historical reality that "abolitionism was born with the American republic." ${ }^{20}$ Abolitionists did not give up as they "worked consistently to destroy slavery and racial injustice in these years [1776-1864], their strategy and tactics constantly evolved." ${ }^{21}$ The antislavery advocates made use of a host of discursive acts and appeals, including nonviolent resistance, petitions, legal briefs, and rational and emotional arguments, and drew upon the religious and Enlightenment principles that many of their audience members found persuasive. David Zarefsky has detailed how the Lincoln-Douglas debates functioned as "both agent and index of social and cultural change,"22 and Garry Wills's close reading of Lincoln's Gettysburg Address illustrates how the speech "makes history" ${ }^{23}$ by "impos[ing] a symbol" to "effect an intellectual revolution. No other words could have done it."24 Lincoln, Wills concludes, used the speech to call "up a new nation out of the blood and trauma" with a revolutionary reading of the Declaration of Independence and the notion of equality. In this speech, Lincoln creates a nation out of the states and demolishes the justification for slavery.

One hundred years later, legal segregation fell to the civil rights movement, which also deployed a sophisticated nonviolent strategy consisting of powerful rhetorical appeals and found support in an emerging progressive political agenda. According to Cornel West, a legacy of success can be claimed from the twentieth-century labor and civil rights movements:

Under Roosevelt the organized power of working people was made legitimate, and under Johnson one-half of all black people and elderly (of all colors) were lifted out of poverty. These achievements-resulting from intense organized struggle — may feel so far away, in both time and possibility, that holding them up as models may seem pointless. But reclaiming this powerful democratic legacy is precisely the mission before the Democratic Party today. ${ }^{25}$

With the assassinations of minister Malcolm X, the Reverend Martin Luther King Jr., and Robert Kennedy, the fragmentation of progressive movements in the late 1960s, and the rise of the New Right, the Roosevelt-Johnson model withered. The failure of the old and new left, and of the larger progressive movement to cultivate common ground, identity, and values expressed in a cogent narrative explains, in part, why the progress made during the civil rights era has crested, and in some ways, regressed. ${ }^{26}$ In the late 1960s, the progressive narrative dissolved into a mélange of competing identity groups, each 
with its own trauma, grievance, and demand. The southern strategy of the Republicans complemented the splintering of the left into "identity groups." This combination produced a conservative majority that divided blacks and whites, many of whom shared economic deprivation.

Lacking a narrative that could braid the ethnic groups around a shared purpose, neoliberals appeased blacks and appealed to whites, playing both sides against the other. Clinton's "Sister Souljah strategy," in which he directly confronted Jesse Jackson to secure a greater share of the Southern white vote, is a prime illustration. ${ }^{27} \mathrm{Al}$ Gore sought but did not achieve a similar opportunity in the 2000 election to distance himself from Reverend Sharpton. Some believe Gore lost because he was perceived to be "an Al Sharpton Democrat." ${ }^{28}$ In the wake of King's death, the civil rights movement, led by men such as Jesse Jackson and Al Sharpton, has failed to craft an effective multiracial narrative.

This history forms the backdrop of the Sharpton and Obama speeches to the 2004 Democratic Convention. Sharpton presented a narrative that invoked the material realities of the racial contract, one that featured African American trauma with a narrative that rehearsed traditional themes, reinforcing the values of those who attended the convention and other like-minded observers, but not reaching beyond them. In contrast, Obama's narrative harkened back to the Roosevelt-Johnson legacy of shared purpose and coalition, and embraced a vision of America grounded in the enlightened ideals of a social contract that espoused human equality, dignity, and justice regardless of race, class status, or ethnic origin.

\section{Sharpton AND Obama AT the 2004 DNC}

In his address, Al Sharpton reminded his audience that Abraham Lincoln signed the Emancipation Proclamation, and that blacks were promised 40 acres and a mule, which they did not receive. Sharpton recounted the failure of America to live up to its promise to black America. He did weave into this thesis references to other ethnic groups, but the speech centered on the civil rights movement and the reparations owed to African Americans. The speech climaxes with this declaration to George Bush:

You said the Republican Party was the party of Lincoln and Frederick Douglass. It is true that Mr. Lincoln signed the Emancipation Proclamation, after which there was a commitment to give 40 acres and a mule. That's where the argument, to this day, of reparations starts. We never got the 40 acres. We went all the way to Herbert Hoover, and we never got the 40 acres. We didn't get the mule. So we decided we'd ride this donkey as far as it would take us. ${ }^{29}$ 
Sharpton's narrative casts George Bush as the obstacle to, and the Democratic Party as a tool for, reparations. His speech fails to sufficiently acknowledge that many whites in the audience were suffering from the aftershocks of their own traumas. The speech also does not grant blacks the agency to deal with the conditions they face nor allow that Democrats and John Kerry needed the adherence of some white southerners to win the White House. While it may be noble and cathartic to speak unvarnished truths, reinforcing the values of those who already agree, African Americans have made the most progress when they have nested their politics and fate in multiracial movements, casting rhetorical visions designed to persuade a composite audience.

Accordingly, Kim Forde-Mazrui argues with great force that the traditional moral claim for reparations, which the Sharpton's speech represents, must be recast. ${ }^{30}$ She marshals evidence that opponents and supporters of affirmative action and reparations can be bridged by rooting the issues in conservative moral terms: "a constructive discourse ... [which] draw[s] upon principles that are either accepted by opponents of affirmative action or are widely accepted by American society as relevant to questions of attributing collective responsibility for the harmful effects of wrongful conduct." ${ }^{31}$ These principles would draw from universal values and set forth a language of justice that transcends race. First, she identifies the need to emphasize corrective justice as a principle, one that applies to all those who have experienced historical injustice. Second, she argues that society and the American nation should be the agent identified as both the cause of the injustice and the source of rectification. Forde-Mazrui's impulse to seize conservative values and use them to ground arguments in favor of reparations and affirmative action represents a constructive alternative to Sharpton's rehearsal.

Using an approach similar to that of Forde-Mazrui, Obama's speech drew from his multiracial background to craft a speech designed to bridge the divides between and among ethnic groups. He writes in his moving autobiography, Dreams from My Father, "I learned to slip back and forth between my black and white worlds, understanding that each possessed its own language and customs and structures of meaning, convinced that with a bit of translation on my part the two worlds would eventually cohere."32 Coherence, Obama writes, is a function of translation and the capacity to move between and among worlds. He was repulsed by whites who used racist language, and could not use the phrase "white folks" as a synonym for bigot as it was undercut by the memories of the love and nonracist impulses of his white mother and grandfather. ${ }^{33}$ His speech at the convention reflects, as McPhail notes, an ability to integrate competing visions of reality. Obama did so by using a rhetorical strategy of consilience, where understanding results through translation, mediation, and an embrace of 
different languages, values, and traditions. This embrace was intended to inspire a "jumping together" to common principles.

His political success in Illinois is due to the use of consilience in search of coherence: Obama devised a narrative approach that acknowledged the traumas experienced by nonblacks, doing so without diminishing the need to address African American exigences. In the process, he enacts consilience, beginning with the multiple traumas affecting the broader community and bridging them to the transcendent value of justice. In his extended New Republic profile, Noam Scheiber observes:

Whereas many working-class voters are wary of African American candidates, whom they think will promote black interests at the expense of their own, they simply don't see Obama in these terms. This allows him to appeal to white voters on traditional Democratic issues like jobs, health care, and education-just like a white candidate would. ${ }^{34}$

Obama, by all reports, appeals to audiences of mixed racial and economic backgrounds. A close reading of his speech to the Democratic convention reveals his use of consilience to achieve coherence.

Obama refers to Lincoln in the beginning and celebrates Jefferson's notion in the Declaration of Independence that "We hold these truths to be self evident, that all men are created equal, that they are endowed by their Creator with certain unalienable rights ..." By using Jefferson as a touchstone, one observer noted, "Obama also broke the mold; African-American politicians have not cited those words without sarcasm and qualification for many years ..." ${ }^{35}$ The choice to feature the value of equality, of course, begins with Jefferson in the eighteenth century, is redefined by Lincoln in the nineteenth to include blacks, and is made urgent by King in the twentieth century. Here, Obama calls for a reaffirmation of American values of equality and liberty, all the while indicating that such precepts have not been fulfilled, and that the country has not lived up to this creed. His use of consilience is in evidence when he includes issues of class, civil liberties, and race in his argument, appealing to a composite audience including Arab Americans, gays, and other identity groups to make use of their shared American values in making their claims.

In addition to reaffirming a commitment to equality, Obama also repeated the word hope 11 times, and the mood of the speech is crystallized by his affirmation of the "audacity of hope." He then inoculates against the response that he was naïve of the need for material change: 
I'm not talking about blind optimism here-the almost willful ignorance that thinks unemployment will go away if we just don't think about it, or the health care crisis will solve itself if we just ignore it. ${ }^{36}$

Without the possibility of hope, there can be no coherence. In turn, Obama roots this call for hope in an "awesome God," one that he was quick to praise as a bridge between blue and red states, and to acknowledge "things unseen." The strategy of consilience is given concrete form when he links members of the composite audience, divided by historical trauma, class, and race, to the values of equality and hope.

The most striking section of the speech is devoted to an elegant paring of contraries (red and blue states, Democrats and Republicans, gay and straight, prowar and antiwar Americans). In so doing, he challenges the binary thinking at the root of racism and other pathologies. He acknowledges the geographical, racial, political, and sexual differences in the United States and situates them in what they share in common:

The pundits like to slice and dice our country into Red States and Blue States; Red States for Republicans, Blue States for Democrats. ... We worship an awesome God in the Blue States, and we don't like federal agents poking around in our libraries in the Red States. We coach Little League in the Blue States ... we've got some gay friends in the Red States. There are patriots who opposed the war in Iraq, and there are patriots who supported the war in Iraq.

The nuance inviting attention is his refusal to obliterate difference or put the individual in service to the many. Most important, he links the suffering of others to his own fate, displaying a rhetorical model of empathy necessary for transformation. There is a sense of the universal that serves the interests of all individuals. Indeed, for progress to be made in this country there is an implicit recognition in Obama's speech that God and the universal principle of equality are necessary.

While he does not feature African American trauma, he does make two comments directly about blacks. First, he challenges the identity politics that undermined the progressive movement in the 1960s by declaring invalid the division of the country by race: "There's not a black America and white America and Latino America and Asian America; there's the United States of America." Second, he presents an expansive sense of agency by pairing actions taken by the government to better secure the welfare of its people with individual initiative. Obama stated, "children can't achieve unless we raise their 
expectations and turn off the television sets and eradicate the slander that says a black youth with a book is acting white." Here, he suggests that blacks themselves have some choice in the values they pursue and their own material fate.

As an Illinois legislator he consistently voted for governmental programs designed to provide economic protection for the poor, and thus the primary agent of structural change in his speech is the government. He gives credit to the GI Bill for the education of his parents and the Federal Housing Authority for the purchase of their home. Inoculating against the claim that people become dependent on federal assistance, Obama notes, "People don't expect government to solve all their problems. But they sense, deep in their bones, that with a slight change in priorities, we can make sure that every child in America has a decent shot at life." Indeed, Obama's economic policies recall the Roosevelt-Johnson legacy of government activism, one that effectively reduced black poverty and abolished de jure racial discrimination. As one strand of a larger rhetoric of consilience, Obama assumes the government can work in concert with other agents to achieve reconciliation and coherence.

In conclusion, a strong case can be made that the frame used to justify reparations and an apology to blacks for their time in slavery should draw on the template displayed in this speech. To effectively work through the traumas faced by blacks, Obama features the "American nation" and the "American society" as the agent of rectification rather than "white people." This distinction becomes critical both in a case for reparations and in a postracial rhetorical theory as it shifts responsibility from the nonessential category of race to that of the American people, a construct with history and legal standing, and commanding the capacity for responsibility. Ultimately, Obama's speech may open up the possibility of an authentic dialogue about race, and provide the narrative necessary for multiracial coalitions and the contact of minds necessary for progressive change. It does so through using a strategy of consilience to achieve reconciliation and coherence.

\section{Mark Lawrence McPhail: Obama's Menexenusian Message}

David Frank's foregoing characterization of Barack Obama's address to the 2004 National Democratic Convention is certainly consistent with my own conceptualization of coherence as a discursive strategy that seeks identification in the face of division. Obama's appeal to "what Lincoln called the better angels of our nature" 37 draws upon the resources of rhetorical coherence in numerous ways: it embraces the ideals of American culture instead of rejecting them; it focuses on those commonalities that connect us instead of invoking the differences that divide us; and it resists argumentative essentialism and 
oppositionality and invokes instead discursive appeals that might reasonably be read as a "strategy for construction of a new order." Obama's speech can, as Frank suggests, be read as a shift away from complicity and toward coherence in African American discourse, and as a postracial or postoppositional rhetoric of consilience that could reconcile the traumatic histories of slavery and segregation and move Americans more effectively toward racial reconciliation. I wish to argue, however, that while Obama's rhetoric of consilience approximates dialogic coherence, it nonetheless falls short of the discursive demands of racial reconciliation.

Obama weaves a therapeutic narrative of opportunity for all, where the "blessed" African (the name "Barak" we are told means "blessed") is blessed with opportunity in a "tolerant" and "generous" America, an America where "you don't have to be rich to achieve your potential." Obama breaks down binary oppositions when he contends that "there's not a liberal America and a conservative America-there's the United States of America. There's not a black America and white America and Latino America and Asian America; there's the United States of America." As such, we "are one people, all of us pledging allegiance to the stars and stripes, all of us defending the United States of America." Obama's appeal to identification and unity illustrates the use of consilience, the linking of diverse voices and values, to achieve coherence, the finding of similarity in difference, of unum in pluribus.

Indeed, Obama draws upon the resources of empathy and identification to envision an undifferentiated America, an America in which "we can tuck our children in at night and know they are fed and clothed and safe from harm," one where we can believe in the "inescapable network of mutuality" dreamt of four decades earlier by another eloquent African American. Obama envisions an America grounded in the

belief that we're all connected as one people. If there's a child on the South Side of Chicago who can't read, that matters to me, even if it's not my child. If there's a senior citizen somewhere who can't pay for their prescription drugs and has to choose between medicine and the rent, that makes my life poorer, even if it's not my grandparent. If there's an Arab American family being rounded up without benefit of an attorney or due process, that threatens my civil liberties. It is that fundamental belief ... that I am my brother's keeper, I am my sisters' keeperthat makes this country work. It's what allows us to pursue our individual dreams yet still come together as one American family.

John W. Rogers Jr., CEO of Ariel Capital Management, compares Obama to Martin Luther King Jr., arguing that he has the potential to "fill an enormous void with his extraordinary gifts," and serve as "a voice for the voiceless." ${ }^{38}$ Like 
King, Obama draws upon coherent principles of identification and empathy that address "the social and psychological divisions that undermine human unity and cooperation." 39 Obama's speech does, as Frank suggests, invoke consilience to achieve coherence by transforming his diverse audiences into one composite audience. Unlike King, however, Obama's ultimately fails to translate consilience into coherence.

While King understood the salience and centrality of race, Obama invites the erasure of race instead of its re-signing, and this is where his oratory departs most radically and most unfortunately from the African American rhetorical tradition of "spiritually inspired militancy." 40 Some who praise Obama argue that "he represents a new form of leadership," one that departs from the traditional concerns of civil rights rhetoric, rhetoric marked by "a willingness to agitate with firebrand conviction and the ability to mobilize large groups of blacks around a common cause." Obama's rhetoric, however, is "less about equal access and more about education and economic opportunities," and Obama aligns his politics with those African American leaders who view "themselves as coalition builders and economic developers seeking to appeal to broad constituencies and abandoning rhetoric that would tag them as liberals." ${ }^{31}$ While there are certainly similarities between Obama and King in terms of rhetorical style, their substantive views on America's racial legacy reveal important differences between King's achievement of coherence and Obama's attempt to reach it through consilience.

While King saw the ideals of democracy and equality as possibilities, Obama idealizes them as actualities. While King called upon America to "be true to what you said on paper," Obama invests the paper declarations of the past with an authority of self-evidence that has yet to be fully realized in the present. While King was powerfully aware of the traumatic histories of slavery, segregation, and white supremacy and the need for the nation as a whole to consciously and conscientiously acknowledge and attend to these histories, Obama conflates these traumas with those of other Americans in a manner that undermines their historical specificity in order to construct a "politics of hope." Obama explains:

I'm not talking about blind optimism here-the almost willful ignorance that thinks unemployment will go away if we just don't think about it, or the health care crisis will solve itself if we just ignore it. I'm talking about something more substantial. It's the hope of slaves sitting around a fire singing freedom songs; the hope of immigrants setting out for distant shores; the hope of a young naval lieutenant bravely patrolling the Mekong Delta; the hope of a millworker's son who dares to defy the odds; the hope of a skinny kid with a funny name who believes that America has a place for him, too. ... The audacity of hope! 
Obama's reduction of black trauma to "slaves sitting around a fire singing freedom songs" romanticizes the historical realities of black suffering and borders on the stereotypical image of the "happy darkie" of traditional racism. His lack of any discussion of race, except to illustrate the ways in which black people are implicated in racism when expressing the belief that "a black youth with a book is acting white," is troubling for much the same reason: it ignores the structural and historical conditions that gave rise to such attitudes. And if one substitutes "race" for either "unemployment" or "health care crisis" in Obama's speech, the silences of "blind optimism" and "willful ignorance" seemingly become acceptable.

In short, Obama's "politics of hope" might be read alternately as what Matthew Frye Jacobson describes as a "politics of disavowal," the rhetorical strategy of conflating the experiences of white ethnics with persons of African descent, and of denying the role of white power and privilege on the demoralizing conditions that continue to disproportionately affect the lives of black folk in America. ${ }^{42}$ Obama's rhetoric, while stylistically appealing, nonetheless ignores the historical and social realities of American racism, realities that Sharpton had the audacity to invoke in his address. Obama's "audacious hope" then, when juxtaposed against Sharpton's audacious truth, leans more toward compromise than either consilience or coherence. And it is this discursive compromise, I believe, that undermines the transformative and emancipatory possibilities of Obama's rhetoric, and limits its potential for achieving coherent reconciliation. Coherence requires connections between principles and practices to create the social transformations it envisions.

Reconciliation similarly requires the creation of "a new common history" and not simply the rehearsal of an old mythology. "It is earned through a sequence of personal acts: of apology, remorse, and restitution, on one side, and by positive forgiveness on the other." ${ }^{33}$ As Mary E. Clark explains, reconciliation involves a very specific set of actions: "first, to address the past as seen by each side; second, to identify common goals for the future; third, to develop concrete projects to meet these goals and begin together to implement them." ${ }^{4}$ Obama's speech fails to address the first of these, and instead embraces a mythological American monologue, a narrative grounded in the ideals of the social contract and painfully ignorant of the realities of the racial contract. By ignoring the concrete social and material realities of America's racial history, and instead invoking the enlightenment ideals of its abstract social mythology, Obama's speech offers a Menexenusian message that, while presented as a praising of all Americans, draws heavily upon the resources of whiteness and its dominant rhetorical tropes: innocence, race neutrality, and positive self-presentation. It articulates well with white racial recovery narratives that silence serious discussions about race in this country. 
Read this way, Obama's speech does not reveal a new trajectory within African American discourse, but a compromise between the acquiescence of assimilationist rhetorics and the oppositionality of revolutionary rhetoric. The public space between these has been inhabited by the integrationist rhetorics of civil rights and social justice, the concerns and themes of which were expressed clearly in Sharpton's speech. Unlike Obama, Sharpton views race as deeply implicated in what the former terms the "long political darkness," but which the latter decries as "a vicious spirit in the body politic." In contrast to Obama's narrative of an idealized America in which race is never mentioned, Sharpton tells the story of America's racial realities, a story in which black men and women crafted the abstractions of freedom, justice, and democracy into lived realities. Sharpton reminds his readers that "a Black man from Barbados named Crispus Attucks" was the first to die in the fight for freedom, a black woman-Fannie Lou Hamer-led the fight for equal political representation, and it was the "firebrand convictions" of a Jesse Jackson that mobilized a victory for the Democratic Party 20 years earlier. Sharpton's speech embodied the very best of the African American tradition of civil rights discourse, oppositional yet inclusive, affirming of fundamental values yet agitating uncompromisingly for their achievement in practice as well as principle.

Indeed, Sharpton's speech is ultimately a call for coherence, one fundamentally grounded in the tradition of spiritually inspired militancy that articulates a strategy of reconstruction for the transformation of race in America. Sharpton's speech also coheres more closely with the rhetorical practices and principles necessary for reconciliation. He explicitly notes the need for an acknowledgment and clarification of history when he counters Bush's attempt to align the Republican Party of the present with "the party of Lincoln and Frederick Douglass." Sharpton iterates, "We got the Civil Rights Act under a Democrat. We got the Voting Rights Act under a Democrat. We got the right to organize under a Democrat." He also demands atonement for the long and sordid history of African American disenfranchisement, enthymemically indicting Bush by invoking the 2000 election: "Mr. President, the reason we are fighting so hard, the reason we took Florida so seriously, is our right to vote wasn't gained because of our age. Our vote was soaked in the blood of martyrs, soaked in the blood of Goodman, Chaney and Schwerner, soaked in the blood of four little girls in Birmingham. This vote is sacred to us. This vote can't be bargained away. This vote can't be given away." Finally, Sharpton's explicit call for reparations fulfills the requirements for reconciliation, and his eloquent observation "we decided we'd ride this donkey as far as it would take us" evokes applause from the audience-almost a full minute-that far surpasses even the most enthusiastic response elicited by Obama. 
Sharpton's speech is therefore, whether viewed from the perspective of coherent or classical rhetorical principles, far superior to Obama's. Like King's, it draws on the resources of an African American tradition of spiritually inspired discourse, and is more concerned with speaking truth to power than praising Athenians in Athens. And like King, Sharpton does not reject the ideals of American history and society, but instead demands that its guardians "be true to what you said on paper." His discourse is dialogic and inclusive, and his invocation of Ray Charles's rendition of "America the Beautiful" is an amazingly powerful and eloquent peroration that re-signs, in the best tradition of black rhetoric, the racial contract: "Mr. President, we love America, not because all of us have seen the beauty all the time. But we believed if we kept on working, if we kept on marching, if we kept on voting, if we kept on believing, we would make America beautiful for everybody." Sharpton tells the unspoken story of American equality, the story in which people of African descent have been instrumental in crafting America's abstract ideals into social realities. ${ }^{45}$

Yet many white commentators demonized Sharpton, and denounced his address as "off message" and "incendiary." ${ }^{16}$ Kimberle Williams Crenshaw reads these criticisms as a troubling example of a larger white recovery project: "One can't help but infer that the media and perhaps some in the Democratic Party just want race to go away. So significant is this sentiment that even Sharpton's act of telling a story of democratic redemption in the face of repressive antidemocratic forces is seen as divisive, off-message and demogogic." 47 The response to Sharpton's call for a continuing commitment to racial justice and social equality might suggest that "America ... doesn't want to hear about it anymore. Al Sharpton's telling of civil history violates their sense of civility, even though everything he said was absolutely true, and to millions of Americans, absolutely relevant." 48 Crenshaw's analysis offers a powerful commentary on the motives underlying the news media's demonizing of Sharpton and praising of Obama, and its potential consequences. She asserts, "The zeal to get beyond race will hasten efforts to drive wedges between black politicians - a move already afoot in the effort to hold up Barack Obama as 'the good black' and Sharpton, Jackson and others as the "bad blacks." 49 This characterization of African Americans in essentialist terms is particularly problematic, Crenshaw notes, because it implies that "the failure to achieve unity on civil rights is the natural consequence of the black discursive tradition, 'I Have a Dream' notwithstanding." ${ }^{50}$ While Obama's speech simply resigned the need to address race in any substantive way, Sharpton's speech re-signed the racial contract, and signified a tradition of spiritually inspired militancy that has called consistently for coherence and been instrumental in concretizing the equalities and freedoms idealized in the social contract. 
Thus, while Crenshaw suggests that the difference between the rhetorics and politics of Sharpton and Obama is "far more a difference of style than substance," ${ }^{51}$ I would counter that their rhetorics are substantively different in terms of their conceptions of race. Indeed, to the extent that Obama departs from this tradition of spiritually inspired militancy that consciously re-signs the racial contract, it is unlikely that his voice will contribute productively to a dialogue about race that can move us closer to reconciliation and transformation. This is, ultimately, what any coherent rhetoric must achieve if it is to be anything more than "mere" rhetoric. It must address the history of traumatic betrayals endured by "every generation of African Americans since the white founders of the U.S. agreed to write a compromise in the Constitution of 1789 to keep African Americans in slavery,"52 and it must move white Americans to acknowledge that history, atone for it, and seek to repair the damage that it has done to the American mind and spirit.

Obama's departure from this tradition and his move toward racelessness will do little to inspire white Americans toward a resigning of the racial contract. While he acknowledges that "we have more work to do," this work consists essentially of "measuring up to the legacy of our forbearers" and "reclaiming" the vision of an idealized America. Obama here imagines an America freed from the traumas of racial history by the "promise" of equality. Yet as Stephen L. Carter explains, this is a vision of America that

almost nobody really believes in but almost everybody desperately wants to. In this vision, we are united in a common enterprise and governed by common consent. Although the nation has problems, some of them caused by racism, we are people of good will, aiming at a fairer, more integrated society, which we will achieve through the actions of our essentially fair institutions. ${ }^{53}$

Carter is responding here to the failed nomination of Lani Guinier, another African American rhetor whose discourse embraced the principles of coherence and who attempted to translate them into social practice. Gunier's analysis of America's racial realities was based not only on idealized representations of American democracy, but on empirical evidence of the dismantling of the Voting Rights Act, largely engineered under President Ronald Reagan, ${ }^{54}$ who, according to Aaron David Gresson III, was the principal architect of the contemporary white recovery project. ${ }^{55}$

Reagan's speech at the Neshoba County Fair in Philadelphia, Mississippi, in 1980, where he unambiguously expressed his support for "state's rights," employed a southern strategy that has been exploited by Republican politicians since Goldwater, "all of whom used coded racial messages to lure disaffected blue collar and Southern white voters away from the Democrats." ${ }^{56}$ The 
politics of white racial recovery gave rise to the anti-affirmative-action and civil rights legislation that shaped the post-civil rights era, undermining racial justice and equality by proclaiming that they had already been achieved: that America was a "color blind" nation, in which African Americans who continued to call for racial justice were asking only for "special privileges," and were guilty of "reverse racism."

Obama's address, and the rhetorical situation that elicited it, must be read against this history of racial recovery in order to accurately assess its potential for racial reconciliation and its potential to persuade white Americans to resign the racial contract. Once weighed against the empirical and material realities of the racial contract, Obama's "audacious hope" seems at best naïve, and at worst opportunistic. On the one hand, it employs a conception of "equality" that is abstract and revisionist, and on the other hand, it fails to address in substantive terms the material realities of African American trauma. Indeed, studies of trauma within the African American context similarly call into question the possibility of Obama's rhetoric successfully reconciling America's racial divisions.

Timothy Brown's exploration of black American trauma can be fruitfully applied to the analysis of Obama's rhetoric. "The production of cultural works that have the potential to address our common humanity is very important, but a political response forces us to see how our cultural productions are implicated in the perpetuation of traumatic violence." ${ }^{.7}$ Psychotherapist Dee Watts-Jones suggests that these cultural productions must be part of an open and honest dialogue that involves both black and white Americans:

Healing from internalized racism eventually includes the freedom to share the pain and shame across groups, because continuing to bear it as our shame alone reinforces oppression. The shame of internalized racism among people of African descent does not belong to us. It is the shame of oppression, and needs to be shared by whites as well. This is part of our healing, and the healing work that whites need to do. ${ }^{58}$

Watts-Jones' insights are particularly important for our discussion of the potential that a rhetoric of consilience holds for the re-signing of the racial contract by African Americans, and its resigning by white Americans. While African Americans will need to continue to cultivate inclusive and affirmative discourses about race, unless white Americans are willing to become part of an honest dialogue about racism that will lead to its resignation, it is unlikely that a coherent understanding of our common humanity can be achieved. Indeed, when just the mention of race leads to demonizing and denial as it did in the case of $\mathrm{Al} \mathrm{Sharpton}$, it is difficult to believe that any rhetorical strategy that 
even touches on the subject will lead to productive conversation about race, much less racial reconciliation.

Thus, I continue to believe that the greatest impediment to racial reconciliation is an unwillingness, largely on the part of people of European descent, to talk openly and honestly about America's long and troubling legacy of racism. Barack Obama's rhetoric of consilience will not, in my view, move us any closer to this much-needed conversation. Because Obama celebrates the abstractions of the social contract while ignoring the realities of the racial contract, his message is unlikely to effect in practice the values it embraces in principle. The connection between these is ultimately the best indication of rhetoric's transformative power, and the greatest impediment to that power is the silence of self-interest and the absence of dialogue. In concluding, we reflect on the ways in which we might transform these impediments into opportunities to move beyond complicity and toward coherent reconciliation in the rhetoric of racism, and perhaps transform our different readings of Obama's speech into a more productive conversation about the problems and possibilities of racial reconciliation.

\section{Wrestling with Our Better Angels: Coherence And Consilience at the Rendezvous of History}

Barack Obama's invocation of Lincoln's reference to "the better angels of our nature" offers a starting point for exploring the commitment to faith that connects the theoretical and critical impulses of both coherence and consilience. Both coherence and consilience are committed to finding a way to wrestle with the painful realities that separate us so that we might better understand the audacious hopes that can bring us together. Like Jacob, whose wrestling with an angel ended in both trauma and transformation, we have sought to examine the ways in which discourse could address deep and painful divisions to, in the words of Aimé Césaire, make "room for all at the meeting-place of conquest." 59 Like Obama, we agree that there is a foundational decency in the American people that we often fail to recognize. With regard to rhetoric, that decency has often been conceived in abstract terms, as a principled commitment to freedom, justice, and equality. With regard to both race and culture, however, those same principles have been realized in practice only after prolonged struggle and sacrifice, and have revealed the limits of both reason and persuasion as they have been conceived in the West. Such limits point to the need for an enlarged conception of rhetoric, one that addresses spirituality as well as rationality, appeals to pathos as well as logos, and celebrates empathy as much as material evidence.

Such a rhetoric also recognizes the importance of understanding human psychology and spirituality for addressing the causes and consequences of 
trauma. Rhetoric is, at its best, a pietho, a talking cure that can facilitate healing when, as James Hillman suggests, it involves "discovering instruments for moving ideas, beliefs, feelings, images and fantasies. Then rhetoric, persuasion, holds major importance. Through words we can alter reality; we can bring into being and remove from being; we can shape and change the very structure of what is real. The art of speech becomes the primary mode of moving reality." 60 Within the context of the traumatic history of race in America, a re-signed rhetoric would address directly the spiritual and material incoherence of white supremacy and black inferiority, and reshape the contours of interest convergence that have thus far limited the possibilities of racial reconciliation. ${ }^{61}$

With Césaire's vision as a polar star, we believe that rhetorical critics in this country can begin to do the hard work necessary to acknowledge that the American problem of the twentieth century, which Du Bois presciently identified as the "color line," has now become a problem of conscience. And even though Barack Obama's rhetoric of consilience is a call to conscience, its resigning of race nonetheless limits its potential for coherent reconciliation. A truly powerful and redemptive narrative would recognize and challenge the separation between an idealized social contract and a realized racial contact, and would interrogate the complicities of whiteness as vigorously as those of blackness. It would decry, in prophetic terms, our mixed record in dealing with race, and issue a clarion call for an unambiguous commitment to racial justice and reparations. One example of this rhetorical ideal is seen in former Mississippi secretary of state Richard Molpus, whose speech at the 40th anniversary of the deaths of James Chaney, Andrew Goodman, and Michael Schwerner reflected powerfully principles of rhetorical coherence and consilience. Molpus offers a coherent acknowledgment of racial reality, and its audaciously hopeful belief in the possibilities of racial reconciliation. ${ }^{62}$ The Molpus address exemplifies an understanding that our "common humanity" is something still to be constructed, not only in symbolic action but in social action as well. It invokes the redemptive possibilities of reason and argumentation as agents of change, which Du Bois affirms in the neglected "Afterthought" of the Souls of Black Folk: "Thus in Thy good time may infinite reason turn the tangle straight, and these crooked marks on a fragile leaf be not indeed." 63

$\mathrm{Du}$ Bois, whose American dream was situated at the intersection of the historical, the rhetorical, and the poetic, recognized that our reconciliation of racial difference would require a willingness to acknowledge the ways in which the color line has shaped not only the souls of black folk, but the souls of white folk as well. ${ }^{64}$ This recognition is compromised when we assume or assert that our collective dreams of freedom and justice have been achieved, 
when in reality they remain, for too many, unrealized. Barack Obama's speech before the 2004 Democratic National Convention reveals this tension between a dream idealized and a dream deferred, between compromise and coherent consilience. It thus provides us with an important opportunity to explore the potential for racial reconciliation from both sides of the color line, to confront the dark angel of race and through the courageous expression of conviction in action, strive to overcome it. It invites us to conceive of a re-signed rhetoric and to dream of the resigning of race. To that end, we conclude in the spirit of audacious hope with the words of Robert Penn Warren, who though positioned on the other side of the color line from $\mathrm{Du}$ Bois, was similarly situated at the intersection of history, rhetoric, and poetry:

For the dream is only a self of yourself-and Jacob once wrestled, nightlong, his angel and, though with wrenched thigh, had blackmailed a blessing, by dawn. ${ }^{65}$

\section{NOTES}

1. See Paul Robeson Jr., "Election 2004: 'Hope Is on the Way," New York Amsterdam News, August 5-August 11, 2004, 13; Erin Aubry Kaplan, "Bringin' Da Funk," LA Weekly, August 6, 2004; Jonathan Tilove, "Boston Events May Be Changing of the Guard in Black Politics," Newhouse News Service, July 27, 2004; and "The Politics of Tokenism," Economist, August 14, 2004, online at Lexis Nexis Academic, September 15, 2004.

2. Chaïm Perelman and Lucie Olbrechts-Tyteca, The New Rhetoric: A Treatise on Argumentation, trans., John Wilkinson and Purcell Weaver (Notre Dame, IN: University of Notre Dame Press, 1969), 21. On Obama's intentions, see Noam Scheiber, "Race against History," New Republic, May 31, 2004, retrieved from Mead: Lexis-Nexis database; and his autobiography, Barack Obama, Dreams from My Father: A Story of Race and Inheritance, rev. ed. (New York: Three Rivers Press, 2004).

3. On the rhetoric of consilience, see Perelman and Olbrechts-Tyteca, The New Rhetoric, 472.

4. Numerous transcripts of both speeches are available. The most accurate reproductions of the speeches are the videos found at http://www.dems2004.org/site, America 2004, the Democratic National Convention website. A version also is also available of Obama's speech in his autobiography, Dreams from My Father, 445-53.

5. Frank's argument is offered in response to McPhail's pessimistic assessment of contemporary race relations outlined in The Rhetoric of Racism Revisited: Reparations or Separation? (Lanham, MD: Rowman and Littlefield, 2002); and McPhail's response to John B. Hatch's essay "Reconciliation: Building a Bridge from Complicity to Coherence in the Rhetoric of Race Relations," Rhetoric \& Public Affairs 6 (2003): 737-64. See Mark Lawrence McPhail, "A Question of Character: Re-Signing the Racial Contract," Rhetoric \& Public Affairs 7 (2004): 391-403.

6. Kimberle Williams Crenshaw, "Sharp Tongues for Sharpton," Nation, August 16, 2004, http://www.thenation.com/doc.mhtml?i=20040816ess= crenshaw. 
7. William Edward Burghardt Du Bois, The Souls of Black Folk (New York: New American Library, 1982), 45.

8. Kimberle Williams Crenshaw, "Sharpton Sharpens the Challenge with an Overtime Victory," Common Dreams Newscenter, January 23 2005, http://commondreams.org/ views04/0730-12.htm.

9. Crenshaw, "Victory."

10. Menexenus by Plato. Translated with an introduction by Benjamin Jowett, http://etext.library.adelaide.edu.au/p/p71mx/menexenus.html.

11. See Aaron David Gresson III, The Recovery of Race in America (Minneapolis: University of Minnesota Press, 1995).

12. For a discussion of the ideological foundation of whiteness and modern racism, see McPhail, The Rhetoric of Racism Revisited, 185-99.

13. See Charles W. Mills, The Racial Contract (Ithaca, NY: Cornell University Press, 1997), 3. Mills's theory of the "Racial Contract" undergirds the distinctions drawn by McPhail between re-signing (i.e., "transforming") and resigning (i.e., "giving up") in "A Question of Character" as well as in the present essay.

14. On this notion, see Perelman and Olbrechts-Tyteca, The New Rhetoric, 14-18.

15. See David Newman in his essay "Writing Together Separately: Critical Discourse and the Problems of Cross-Ethnic Coauthorship," Area 28 (1996): 1-12, on the difficulties of interethnic scholarly collaboration.

16. Jerome D. Frank and Julia B. Frank, Persuasion and Healing: A Comparative Study of Psychotherapy, 3rd ed. (Baltimore: Johns Hopkins University Press, 1991), 3.

17. See especially Dominick LaCapra, History in Transit: Experience, Identity, Critical Theory (Ithaca, NY: Cornell University Press, 2004).

18. Kim Forde-Mazrui, “Taking Conservatives Seriously: A Moral Justification for Affirmative Action and Reparations," California Law Review 92 (2004): 683-753.

19. Lee A. Daniels, Rose Jefferson-Frazier, and the National Urban League, The State of Black America (New York: National Urban League, 2004).

20. Richard S. Newman, The Transformation of American Abolitionism: Fighting Slavery in the Early Republic (Chapel Hill: University of North Carolina Press, 2002), 2.

21. Newman, The Transformation of American Abolitionism, 2.

22. David Zarefsky, Lincoln, Douglas, and Slavery: In the Crucible of Public Debate (Chicago: University of Chicago Press, 1990), xii.

23. Garry Wills, Lincoln at Gettysburg: The Words That Remade America (New York: Simon and Schuster, 1992), 174.

24. Wills, Lincoln at Gettysburg, 174-75.

25. Cornel West, Democracy Matters: Winning the Fight against Imperialism (New York: Penguin Press, 2004), 34.

26. Todd Gitlin, The Twilight of Common Dreams: Why America Is Wracked by Culture Wars (New York: Metropolitan Books, 1995).

27. Jack W. Germond and Jules Witcover, Mad as Hell: Revolt at the Ballot Box, 1992 (New York: Warner Books, 1993), 300-305.

28. Jeremy D. Mayer, Running on Race: Racial Politics in Presidential Campaigns, 1960-2000 (New York: Random House, 2002), 291. 
29. Sharpton DNC speech. All quotations are taken from the transcript citation listed in note 4.

30. Forde-Mazrui, "Taking Conservatives Seriously."

31. Forde-Mazrui, "Taking Conservatives Seriously," 693.

32. Obama, Dreams from My Father, 82.

33. Obama, Dreams from My Father, 81.

34. Noam Scheiber, "Race against History," New Republic, May 31, 2004, online at Lexis Nexis Academic, September 7, 2004.

35. Scott L. Malcomson, “An Appeal Beyond Race,” New York Times, August 1, 2004, sec. 4, 5.

36. Obama DNC Speech. All quotations are taken from the transcript cited in note 4.

37. "Interview with Barack Obama," The Charlie Rose Show, November 23, 2004.

38. Kenneth Meeks, "Favorite Son," Black Enterprise 35 (October 2004): 95.

39. Mark Lawrence McPhail, Zen in the Art of Rhetoric: An Inquiry into Coherence (Albany: State University of New York Press, 1996), 87.

40. Mark Lawrence McPhail, "Dessentializing Difference: Transformative Visions in Contemporary Black Thought," Howard Journal of Communications 13 (2002): 77-95.

41. Meeks, "Favorite Son," 95.

42. See Matthew Frye Jacobson, Whiteness of a Different Color: European Immigrants and the Alchemy of Race (Cambridge, MA: Harvard University Press, 1998), 279-80.

43. Mary E. Clark, In Search of Human Nature (London: Routledge, 2002), 364.

44. Clark, In Search of Human Nature, 368.

45. See Celeste Michelle Condit and John Louis Lucaites, Crafting Equality: America's AngloAfrican Word (Chicago: University of Chicago Press, 1993).

46. Crenshaw, "Sharp Tongues."

47. Crenshaw, "Sharp Tongues."

48. Crenshaw, "Sharp Tongues."

49. Crenshaw, "Sharp Tongues."

50. Crenshaw, "Sharp Tongues."

51. Crenshaw, "Sharp Tongues."

52. John Alan, "Kerry Misquotes Hughes," http://www.newsandletters.org/Issues/2004/August-September/ BRV_August2004.htm.

53. Stephen L. Carter, foreword, in Lani Guinier, The Tyranny of the Majority: Fundamental Fairness in Representative Democracy (New York: Free Press, 1994), xiii.

54. For a rhetorical analysis of Guinier's critique of Reagan's attack on Voting Rights Act and her resulting demonization in the media, see Kathryn Kañas and Mark Lawrence McPhail, "Demonizing Democracy: The Strange Career of Lani Guinier," in New Approaches to Rhetoric, ed. Patricia A. Sullivan and Steven R. Goldzwig (Thousand Oaks, CA: Sage, 2004), 223-44.

55. Gresson, The Recovery of Race in America, 10.

56. Jack White, "Lott, Reagan and Republication Racism," http://www.time.com/time/nation/ article/ 0,8599,399921,00.html.

57. Timothy Brown, "Revisiting the Subject of Trauma," Global Black News, October 11, 2004, http://www.globalblacknews.com/brown_trauma.html. 
58. Dee Watts-Jones, "Healing Internalized Racism: The Role of Within-Group Sanctuary Among People of African Descent," Family Process 41 (2002): 595-96.

59. Aimé Césaire, Return to My Native Land, trans. John Berger and Anna Bostock (Baltimore, MD: Penguin Books, 1969), 85.

60. James Hillman, "On the Necessity of Abnormal Psychology: Ananke and Athena," in Facing the Gods, ed. James Hillman (Irving, TX: University of Dallas Press, 1980), 21.

61 Kirt Wilson argues that interest convergence has functioned to sustain white privilege while creating the illusion of black progress. See "Is There Interest in Reconciliation?" Rhetoric \& Public Affairs 7 (2004): 367-77.

62. See Richard Molpus, "40th Commemoration Speech," Philadelphia, Mississippi, Coliseum, June 20, 2004.

63. Du Bois, The Souls of Black Folk, 278.

64. For a consideration of connections between double-consciousness and rhetoric, see Mark Lawrence McPhail, "Double Consciousness in Black and White: Identity, Difference, and the Rhetorical Ideal of Life," The Van Zelst Lecture in Communication (Evanston, IL: Northwestern University School of Speech, 2001).

65. Robert Penn Warren, “Dream," Now and Then: Poems 1976-1978 (New York: Random House, 1987), 29. 
Copyright of Rhetoric \& Public Affairs is the property of Michigan State University Press and its content may not be copied or emailed to multiple sites or posted to a listserv without the copyright holder's express written permission. However, users may print, download, or email articles for individual use. 